УДК 159.955:37

DOI: 10.37026/2520-6427-2020-104-4-118-120
Віта ОВДІЙчук,

аспірантка ПВНЗ «Міжнародний

економіко-гуманітарний університет

імені академіка Степана Дем'янчука», м. Рівне

\title{
ФІЛОСОФСЬКІ ОСНОВИ ПОНЯТТЯ КРИТИЧНОГО МИСЛЕННЯ
}

У статті розглянуто поняття «критичне мислення» у філософсько-освітньому дискурсі, розкрито його важливість як одного із наскрізних умінь, яким має володіти майбутній учитель інформатики. Доведено, щзо ие один із визначальних факторів успіху на професійній ниві та особистісному розвитку в умовах модернізаиї та інформатизаиії суспільства.

Ключові слова: пізнання, мислення, критичне мислення, розвиток критичного мислення, майбутні вчителі інформатики, заклад вищоӧ освіти.

The article considers the development trends of the concept of "critical thinking» in philosophical and educational discourse, which today has become important as one of the cross-cutting abilities that a future IT teacher should possess, as one of the various factors of success in the professional area and the personal development in the conditions of society modernization.

It was established that the concept of critical thinking dates back to the ancient times. Scientists attached the great importance to the ability of thinking, critical world cognition, logical thinking, paid attention to the man's critical attitude to the subject and process of cognition, and proposed their own methods of finding the truth, based on mind, thinking. Critical thinking, as a term, appeared in the second half of the last century and it was regarded by researches as a certain type of thinking.

It was defined that a key role in the development of critical thinking belongs to education. During the educational process between the teacher and the student there is a constructive dialogue, in the process of which the problematization of a certain situation, phenomenon, the search for optimal ways to solve the problem are taken.

Critical thinking transforms ordinary learning into a productive educational process. It was found that the critical thinking personality is characterized by the ability to search for facts, analyze them on their own, make conclusions based on reliable data,objectively assess various facts, argue their own position, admit and correct their mistakes, resist to negative informational influence and manipulations. Such skills characterize a critical-thinking person, promote to professional self-realization,provide an opportunity to change their lives and the lives of others for the best.

Key words: cognition, thinking, critical thinking, development of critical thinking, future teachers of computer science, institution of higher education.

Постановка проблеми. Пандемія респіраторної хвороби, спричинена коронавірусною інфекцією COVID-19, глобальне зниження економічної активності та стрімкий розвиток комп'ютерних технологій ставлять нові виклики перед українським суспільством й освітою передовсім. На офіційному сайті Світового економічного форуму у жовтні 2020 року було опубліковано «Звіт про майбутнє робочих місць за 2020 рік» (The Future of Jobs Report 2020), який містить актуальну інформацію про перспективи, прогнози розвитку ринку праці, впровадження технологій, зріст попиту на певні навички і вміння, якими мають володіти спеціалісти на найближчі п'ять років. У документі наведено топ 15 навичок, які будуть затребувані до 2025 року: аналітичне мислення та інновації; комплексне вирішення проблем; критичне мислення та аналіз; креативність, оригінальність та ініціативність; лідерство і соціальний вплив; технологічний дизайн та програмування; стійкість, стресостійкість, гнучкість та інші [1].

Серед цих наскрізних умінь критичне мислення та аналіз, вирішення проблем залишаються у центрі уваги впродовж останніх років. Ці вміння є спільними для наукових, творчих, мистецьких, професійних, загальних компетентностей, які $\epsilon$ необхідними для успішної професійної діяльності та самореалізації у сучасному світі. У зв'язку з цим одним із пріоритетних завдань вітчизняної вищої освіти є підготовка висококваліфікованих фахівців, зокрема вчителів інформатики, здатних до критичного мислення.

Аналіз наукових досліджень і публікацій. Огляд наукових праць свідчить про те, що у зарубіжній та вітчизняній науках активно досліджується проблема критичного мислення, його розвитку під час освітньої діяльності. Термін «критичне мислення» був уперше вжитий закордонними психологами наприкінці минулого століття. Фундаторами критичного мислення $є$ Е. де Боно, В. Джеймс, Дж. Дьюї, Д. Клустер, М. Ліпман, К. Мередіт, Р. Поль, Ч. Темпл, П. Фрейре, Д. Халперн та інші, які активно займалися дослідженням цієї проблеми. Серед сучасних науковців варто відзначити А. Авершина, Л. Києнко-Романюк, О. Пометун, М. Починкову, А. Соломенка, О. Тягла, С. Терна, Т. Яковенко та інших. Вчені по-різному трактують це поняття, пропонують різні шляхи розвитку критичного мислення особистості, проте сьогодні важливо з'ясувати історичні витоки цього терміна, його сутність і роль у філософсько-освітньому дискурсі.

Зважаючи на означену проблему, мета нашого дослідження полягає у 3'ясуванні походження, сутності, ролі критичного мислення, яке на сучасному етапі розвитку української освіти набуває важливого теоретичного і практичного значення. 
Виклад основного матеріалу. Поняття «критичне мислення» бере початок із часів античності. У працях давньогрецьких філософів Аристотеля, Геракліта, Демокрита, Сократа, Платона та інших уже містяться окремі описи, які характеризують діяльність критичної особистості. Запропонований Сократом, потім розвинений його послідовником Платоном, метод бесіди, діалогу, під час якого між співбесідниками відбувається встановлення істини, розв'язання проблемного питання, сприяв розвитку критичності до встановлених раніше понять та явищ, позитивно впливав на зародження та подальший розвиток логіки як науки [11].

За Аристотелем, мислення є частиною душі, яке так само, як і душа, невіддільні від тіла. Мислення $є$ діяльністю, яка спрямована на пізнання сущого. Воно може бути і правильним, і неправильним: правильне це розуміння, пізнання та істинна думка, а неправильне - протилежне їм. Досліджуючи мислення, філософ сформулював основні закони логіки, створив вчення про умовиводи [2].

Видатний мислитель доби Відродження М. Кузанський виступав проти мислення, заснованого на авторитаризмі. У своїх дослідженнях учений відокремлював розум від розсудку і доводив, що розсудок, роблячи висновки, не знає, про що вони, а розум надає таким міркуванням ясності і форми. «Бо розум ухвалює судження та розрізняє, яке міркування правильне і яке софістичне. Розум також є розпізнавальною формою актів розсудку як розсудок - розпізнавальна форма відчуттів і уявлень» [9, с. 402].

Розмежування розуму i розсудку набуло подальшого розвитку в німецькій класичній філософії (I. Кант, Г. Гегель). І. Кант уперше чітко розмежовує розум і розсудок як рівні мислення: на розсудкові грунтується наукове знання, на розумі - філософія (метафізика). Філософ був проти будь-якого догматизму, вважав, що критика може зарадити пануванню безвір'я, марновірства, фантазування, різних хибних думок. Догматичне застосування розуму без критики веде до появи безпідставних тверджень, скептицизму, і лише критика розуму веде до науки. Своєю критичною філософією мислитель заклав фундамент для розвитку теорії критичного мислення [5].

Досліджуючи різні способи пізнання дійсності, визначні філософи Просвітництва Т. Гоббс, Р. Декарт, Дж. Локк та інші звертали увагу на критичне ставлення людини до предмета та процесу пізнання і пропонували власні методи пошуку істини, опираючись на розум і мислення. Р. Декарт, наприклад, радить піддавати сумнівам істинність раніше встановлених тверджень, уникати поспіху та упередження, розпочинати з простого та очевидного і рухатися до складного, робити висновки на основі фактів, використовувати інтуїцію розуму та дедукцію (або індукцію) для встановлення правдивості, достовірності судження, а також зазначає, що розуму можуть у цьому сприяти або перешкоджати уява, почуття і пам'ять [3]. У Р. Декарта сумнів, недовіра до твердження, істинність була уже встановлена, набуває важливого значення, стає основою для його відомого вислову «Cogito ergo sum». «Стан сумніву є необхідним моментом розвитку теоретичного, наукового мислення, який дає можливість подолати синдром «загальновизнаності», здійснити критичний аналіз стосовно ідей, що вважалися неспростовними» [13, с. 616]. Мислитель Дж. Локк пропонує розглядати ідеї у різних відношеннях та звичайних зв'язках, виокремлювати факти та на їх основі робити обгрунтовані висновки, об'єктивно ставитися до речей, розрізнювати та групувати, проводити аналогію та асоціацію, здійснювати пошук істини, зосереджуючи свою увагу на суттевих питаннях, не відволікатися від мети [7].

Засновник критичного раціоналізму К. Поппер акцентує увагу на важливості методу раціональної дискусії для пошуку істини, суть якого полягає у чіткому і зрозумілому формулюванні обговорюва-

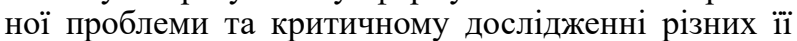
розв'язків. Дослідник наголошує, що він ототожнює раціональну установку з критичною: будь-яке запропоноване власне вирішення проблеми ми маємо не захищати, а повинні намагатися спростувати. I саме така критична установка, на думку філософа, характеризує науковця. Кожен повинен піддавати критиці власні міркування, бо інакше його почнуть критикувати інші. Така критика буде результативною, якщо проблема, яку потрібно вирішити, та їі рішення сформульовані чітко та зрозуміло [12].

До середини XX століття термін «критичне мислення» науковці не використовували, проте вони вкладали в зміст цього поняття правдиве, істинне пізнання навколишнього світу: піддавати сумнівам раніше встановлені твердження, робити висновки на основі достовірних фактів, уникати упереджень і поспіху, аргументувати свою позицію, дискутувати, логічно мислити, бути критичним.

Видатний американський науковець Дж. Дьюї, один із основоположників ідеї критичного мислення, у своїх працях розкриває важливість перетворення природних здібностей у навички критичного розгляду та дослідження під час освітнього процесу. Головним завданням у таких навичках $є$ сформувати вміння не робити поспішних висновків та опанувати різні методи пошуку нового матеріалу, щоб підтвердити або спростувати найперше, що спало на думку (інакше «перед нами - некритичне мислення, minimum рефлексії»). Рефлексія дозволяє поглянути на предмет досліджень із різних боків, ретельно дослідити та зробити правильні висновки. Дослідник пише, що рефлексивне мислення - це логічний тип мислення, якому притаманні обережність, грунтовність, точність, визначеність, правильність, методична побудова. У Дж. Дьюї рефлексивне мислення є синонімом критичного [4, с. 12].

У другій половині XX століття критичне ставлення до навколишнього світу набуває особливого значення, адже зміни у політичному світі провладних режимів, наростання хвилі демократизації, 3 одного боку, та технічним прогресом, появою різноманітних технічних засобів роботи 3 інформацією - 3 іншого, сприяли виникненню нових різноманітних поглядів, думок, стилів поведінки, які потребували критичного осмислення. За П. Фрейpe, людина, яка постійно розвиває у собі критичне ставлення до навколишнього світу, перестає бути пасивним спостерігачем і активно втручається у навколишню дійсність, змінює іiі, стає «інтегрованою особистістю», «утверджується як суб'єкт». У формуванні критичного ставлення головна роль належить саме критичній освіті, основою якої є діалог. 
У діалозі педагога і здобувача освіти відбувається проблематизування певного об'єкта, співпраця у процесі пізнання, спілкування, народжується знання [14, с. 20-22], адже освіта - це не просто передача знань від тих, хто знає, до тих, хто не знає. Ця думка П. Фрейре співзвучна $з$ думкою американського філософа М. Ліпмана, який у своїх працях відстоює рефлексивну парадигму критичної практики (методичної діяльності), протиставляючи іiі стандартній парадигмі звичайної практики. Педагог повинен заохочувати студентів до пізнання навколишнього середовища, надавати їм автономію під час навчання, презентувати знання про світ двозначно, неточно, у такий спосіб спонукати їх до дослідження, рефлексії. У такому випадку діти стають вдумливими, рефлексивними, розсудливими, розважливими, вчаться вести дискусію, формулювати власні міркування, у них розвивається мислення вищого порядку, до складу якого входять критичне та творче мислення $[14 ; 10]$.

Теперішні здобувачі освіти під час навчання та поза ним перебувають у потужному потоці інформації, яка поширюється надзвичайно швидко через стрімкий розвиток та розповсюдження новітніх інформаційно-комунікаційних технологій і яка потребує опрацювання, перетворення, перевірки тощо. Інформація $\epsilon$ основою для критичного мислення. Критичне мислення розпочинається з постановки запитань і з'ясування проблем, які потрібно вирішити, перетворює навчання в цілеспрямовану інтелектуальну діяльність, освітній процес стає продуктивним, безперервним. Це мислення націлене на переконливу аргументацію, адже критично-мисляча людина, яка володіє вагомими аргументами, може протистояти стереотипам, нею складно маніпулювати. Критичне мислення відіграє й соціальну роль, яка виявляється у розвитку комунікативних здібностей, умінні знаходити порозуміння [6], є «одним із головних принципів освоєння світу», «орієнтує людину на творення себе в напрямі гармонізації з суспільством та природою» [8, с. 299].

Для того, щоб у сучасних умовах студенти стали компетентними фахівцями, вони повинні самостійно досліджувати об'єкти, здійснювати пошук фактів, робити висновки на основі достовірних даних, давати об'єктивну оцінку різним явищам, мати власну, обгрунтовану думку, вміти визнавати та виправляти свої помилки, протистояти негативному інформаційному впливу, маніпуляціям. Такі вміння характеризують критично-мислячу особистість, сприяють професійній самореалізації, надають можливість змінити своє життя та життя оточення на краще.

Висновки. Аналіз філософсько-освітнього дискурсу свідчить, що критичне мислення бере свій початок ще $з$ античних часів. Науковці надавали вагомого значення умінню міркувати, критично пізнавати світ, логічно мислити, що сприяло встановленню істини, правди. Критичне мислення як термін з'явився у другій половині минулого століття, під ним науковці розуміли певний тип мислення, який сприяє об'єктивному пізнанню навколишнього світу, розвитку певних умінь і навичок, які необхідні для розв'язання життєвих задач і є важливими для особистісного та професійного зростання. Ключова роль у розвитку такого типу мислення належить освіті. Ефективність освітнього процесу залежить від педагога, рівня його критичного мислення, уміння перетворити заняття на конструктивний діалог, під час якого відбувається проблематизування певної ситуації, дослідження об'єктів, народжуються знання. Саме в таких умовах формується критично-мисляча, творча особистість.

Проблема розвитку критичного мислення $є$ актуальною для сучасної української освіти, тому перспективу наступних досліджень ми вбачаємо у грунтовному дослідженні теоретико-методологічних аспектів упровадження технології розвитку критичного мислення у процес фахової підготовки майбутніх учителів інформатики у закладах вищої освіти.

\section{СПИСОК ВИКОРИСТАНОЇ ЛІТЕРАТУРИ}

1. The Future of Jobs Report 2020. URL: https:// www.weforum.org/reports/the-future-of-jobsreport-2020 (дата звернення: 22.10.2020).

2. Аристотель. О душе. Сочинения : в 4 т. Москва : Мысль, 1976. Т.1. С. 370-448.

3. Декарт Р. Сочинения : в 2 т. ; пер. с лат. и франц. / сост., ред. В. В. Соколова. Москва : Мысль, 1989. Т. 1.654 c.

4. Дьюи Д. Психология и педагогика мышления ; пер. с англ. Н. М. Никольской. Москва : Совершенство, 1997. 208 с. URL: http://pedlib.ru/ Books/2/0136/2 0136-12.shtml\#book page top (дата звернення: 01.11.2020).

5. Кант I. Критика чистого розуму ; пер. 3 нім. та приміт. І. Бурковського. Київ : Юніверс, 2000. 504 с.

6. Клустер Д. Что такое критическое мышление? URL: http://testolog.narod.ru/Other15.html (дата звернення: 19.08.2020).

7. Коменский Я. А., Локк Д., Руссо Ж.-Ж., Песталоцци М. Г. Педагогическое наследие / сост. В. М. Кларин, А. Н. Джуринский. Москва : Педагогика, 1988. С. $138-192$.

8. Критичне мислення: освіта, творчість, цінності : монографія / за заг. ред. В. Г. Кременя. Київ : Інститут обдарованої дитини НАПН України, 2017. 299 c.

9. Кузанский Н. Сочинения : в 2 т. ; пер, общ. ред. и вступ. статья 3. А. Тажуризиной. Москва : Мысль, 1979. T. 1. 488c.

10. Липман М. Рефлексивная модель практики образования. Философия для детей. Москва : ИФРАН, 1996. С. 90-112.

11. Платон. Діалоги. 2-е вид. ; пер. 3 давньогр. Й. Кобіва, У. Головач, Д. Коваль, Т. Лучука, Ю. Мушака. Київ : Основи, 1999. 395 с.

12. Поппер К. Логика и рост научного знания. Избранные работы ; пер. с англ. Л. В. Блинникова, В. Н. Брюшинкина, Э. Л. Наппельбаума, А. Л. Никифорова / общая ред. и вступ. статья В. Н. Садовского. Москва : Прогресс, 1983. 605 с.

13. Філософський енциклопедичний словник / НАН України ; Ін-т філософії ім. Г. С. Сковороди ; редкол. : В. І. Шинкарук (голова) та ін. Київ : Абрис, 2002. $742 \mathrm{c}$.

14. Фрейре П. Формування критичної свідомості ; пер. 3 англ. О. Дем'янчука. Київ : Юніверс, 2003. $17 \mathrm{c}$.

Дата надходження до редакиії: 14.11.2020 p. 